\title{
水熱合成 $(\mathrm{K}, \mathrm{Na}) \mathrm{NbO}_{3}$ 厚膜の組織観察
}

東北大学金属材料研究所 白石貴久木口賢 紀 今野豊彦
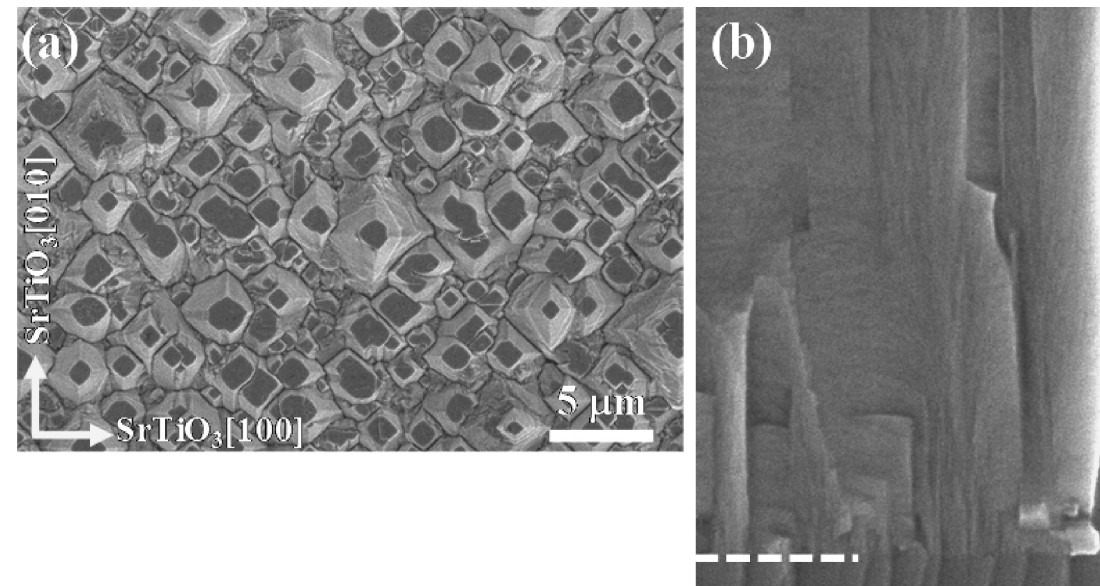

$\mathrm{La}: \mathrm{SrTiO}_{3}$ sub.

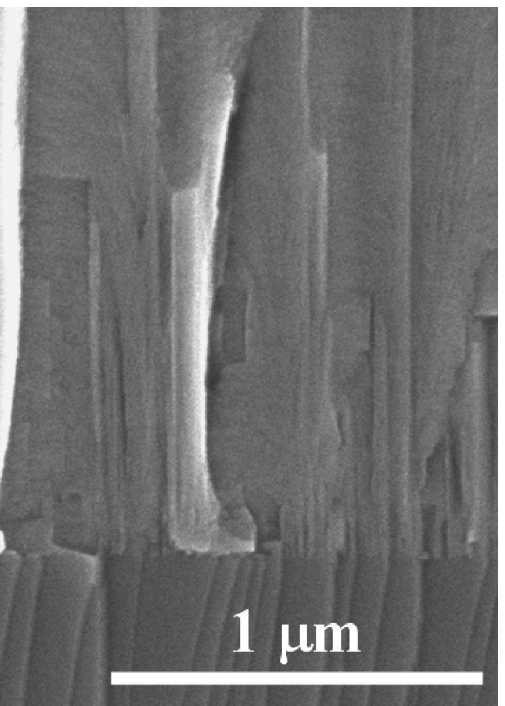

Fig. 1 SEM による $(\mathrm{K}, \mathrm{Na}) \mathrm{NbO}_{3}$ 膜の (a)表面像と (b) 断面像.

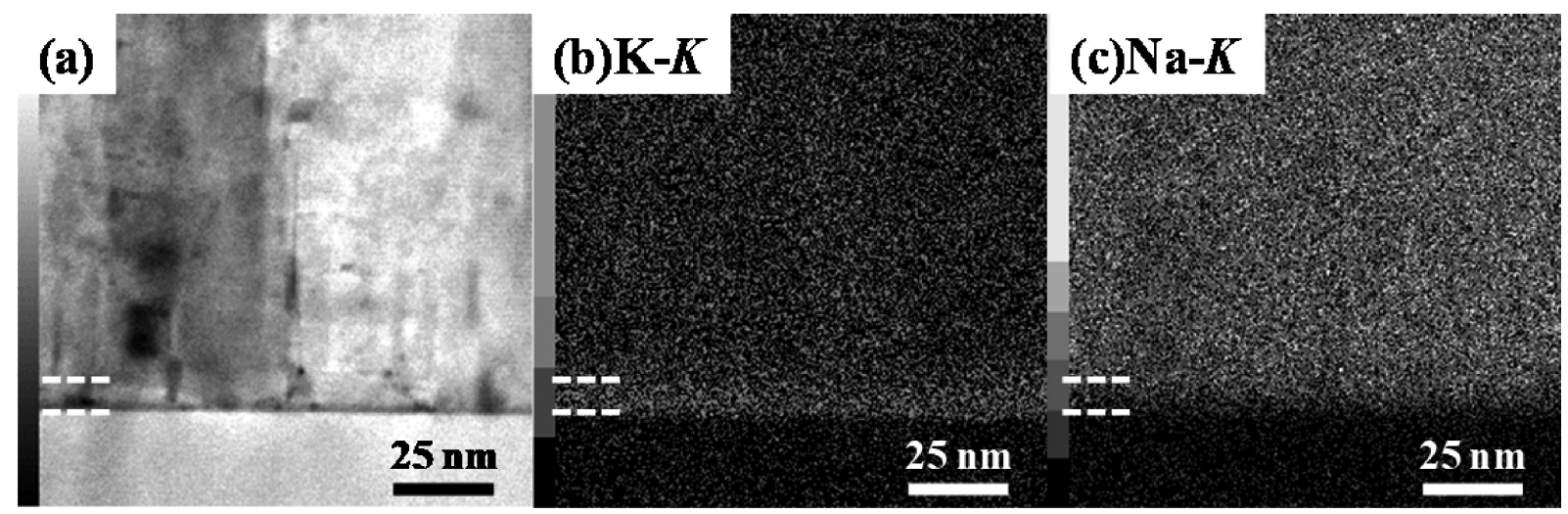

Fig. 2 (K, Na) $\mathrm{NbO}_{3}$ 膜の (a)LAADF-STEM 像と (b), (c)STEM-EDS マッピング像.

圧電体膜をセンサデバイスに応用する際, 数 $\mu \mathrm{m}$-数百 $\mu \mathrm{m}$ 程度の膜厚が求められる. 本研究では, 強アルカリ溶液中で 材料合成を行う水熱法の特徵を活かして, 種々の膜厚範囲に 対応可能な製膜手法の確立を目指している，そこで，膜厚 3 $\mu \mathrm{m}$ の圧電体 $(\mathrm{K}, \mathrm{Na}) \mathrm{NbO}_{3}$ 膜を (100) $\mathrm{SrTiO}_{3}$ 基板上に作製 し，マルチスケールでの組織観察を行うことで，組成分布や 製膜過程を調査した.

Fig. 1 は SEM による (a)膜表面と (b)膜断面の観察像を示 している. 膜表面には柱状組織が観察されたことから, 製膜 過程は柱状成長であると推測される。 また，それぞれの組織 は基板に対して一定の方位関係を持っていることから， (001)にエピタキシャル成長していることが分かった。さら
に，断面像から空孔は観察されず，緻密な膜が堆積している ことも分かった．Fig. 2 は，膜-基板界面での STEM-EDS の結果を示している. マクロスコピックには K と Na が膜 中に均一に分布しているが, 基板直上の $10 \mathrm{~nm}$ 程度の領域 に拉て K K と Naのコトラストが逆転していた。これ は，製膜初期段階において $\mathrm{Na}$ が多く含まれていることを意 味している.

以上より，水熱法により高品質な圧電体厚膜の作製が可能 であることが示唆され，製膜過程に関する知見を得ることが できた.

(2018年 8 月20日受理) [doi:10.2320/materia.58.84]

Texture Observation for Hydrothermally-synthesized (K, Na) $\mathrm{NbO}_{3}$ Thick Films; Takahisa Shiraishi, Takanori Kiguchi and Toyohiko J. Konno

Keywords: SEM (scanning electron microscopy), STEM (scanning transmission electron microscopy), EDS (energy dispersive spectrometry) TEM specimen preparation: ion milling TEM utilized: JEM-ARM200F (200 kV) 